\title{
PENGARUH KEPEMIMPINAN DAN MOTIVASI KERJA TERHADAP KINERJA KARYAWAN PT. PERKEBUNAN NUSANTARA IV (PERSERO) MEDAN
}

\author{
Aprinawati \\ Dosen Jurusan Manajemen Fakultas Ekonomi Universitas Negeri Medan
}

\begin{abstract}
Abstrak
Salah satu permasalahan yang sering timbul dalam organisasi adalah penurunan kinerja karyawan. Tinggi rendahnya kinerja pegawai ternyata dipengaruhi oleh banyak factor seperti factor kepemimpinan dan motivasi. Penelitian ini bertujuan untuk mengetahui seberapa besar pengaruh kepemimpinan dan motivasi kerja terhadap kinerja pada PT. Perkebunan Nusantara IV (Persero) Medan. Teknik analisis data yang digunakan dalam penelitian ini adalah Analisis Jalur dengan rumus $Y=P y X_{1}+P y X_{2}+$ E. Untuk mengetahui besarnya pengaruh kepemimpinan dan motivasi secara simultan dapat dilihat dari perhitungan determinasi $\left(R^{2}\right)$, sedangkan untuk mengetahui besarnya pengaruh langsung variable kepemimpinan terhadap kinerja karyawan digunakan rumus $\rho_{y} X_{I}^{2}$ dan untuk mengetahui besarnya pengaruh langsung variabel motivasi kerja terhadap kinerja karyawan digunakan rumus $\rho_{y} X_{2}^{2}$. Setelah data dianalisis, maka diperoleh persamaan analisis jalur $Y=0,459 X_{1}+0,436 X_{2}+0,640$ E1. Selanjutnya nilai koefisien determinasi $\left(R^{2}\right)$ sebesar 0,591 yang memiliki arti bahwa kepemimpinan dan motivasi kerja secara simultan mempengaruhi kinerja karyawan sebesar 59,1\% dan sisanya 40,9\% disebabkan faktor-faktor lain. Sehingga dapat disimpulkan bahwa hipotesis diterima yang artinya ada pengaruh antara kepemimpinan dan motivasi kerja terhadap kinerja karyawan PT. Perkebunan Nusantara IV (Persero) Medan.
\end{abstract}

Keyword: Kepemimpinan, Motivasi Kerja, Kinerja karyawan

\section{PENDAHULUAN}

Dalam organisasi, sumber daya manusia memegang peranan penting untuk menjalankan aktivitas dan mencapai tujuan dengan efektif dan efisien. Sumber daya manusia merupakan tokoh sentral dalam organisasi maupun perusahaan. Agar aktivitas manajemen berjalan baik, perusahaan harus memiliki karyawan yang berpengetahuan dan berketrampilan tinggi serta usaha untuk mengelola perusahaan seoptimal mungkin sehingga kinerja karyawan terus meningkat. Kinerja yang baik adalah kinerja yang optimal, yaitu kinerja yang sesuai standar organisasi dan mendukung tujuan organisasi.
Kinerja merupakan proses tingkah laku seseorang sehingga ia menghasilkan sesuatu yang menjadi tujuan dari pekerjaannya. Perbedaan kinerja antara seseorang dengan lainnya adalah dikarenakan perbedaan karakteristik dan individu. Selain itu, seseorang dapat menghasilkan kinerja yang berbeda di dalam situasi yang berbeda. Semua hal tersebut menjelaskan bahwa kinerja pada dasarnya dipengaruhi oleh beberapa factor diantaranya kepemimpinan dan motivasi kerja.

Kedudukan pemimpin dalam suatu perusahaan sangat lah penting dalam hal mencapai tujuan organisasi. Berhasil atau tidaknya suatu perusahaan, sebagian besar ditentukan oleh mutu kepemimpinan yang 
dijalankan oleh orang-orang yang diserahi tanggung jawab untuk memimpin perusahaan tersebut. Pemimpin tidak hanya sekedar memberikan tugas-tugas atau pekerjaan, tetapi juga harus memberikan pengarahan mengenai pekerjaan yang di berikan. Pemimpin seharusnya menjadi sosok yang dijadikan panutan yang di segani oleh bawahannya bukan ditakuti oleh bawahannya.

Salah satu permasalahan yang sering timbul dalam organisasi adalah penurunan kinerja karyawan. Tinggi rendahnya kinerja pegawai ternyata dipengaruhi oleh banyak faktor seperti faktor kepemimpinan dan motivasi. Melalui pemberian motivasi kepada karyawan dengan melihat kebutuhan mereka, baik kebutuhan fisiologis maupun aktualisasi diri, diharapkan dapat lebih meningkatkan kinerja mereka. Oleh karena itu, diperlukan motivasi kerja yang dapat memberikan dorongan kepada karyawan untuk bekerja lebih baik.

Motivasi merupakan suatu hal yang mengakibatkan seseorang menyelesaikan pekerjaannya dengan semangat, rela dan penuh tanggung jawab. Banyak hal yang dapat mempengaruhi keberhasilan dalam memotivasi karyawan, hal ini tergantung dari cara organisasi atau perusahaan dalam mengelola faktorfaktor yang terkait sehingga tujuan motivasi dapat berjalan sesuai rencana. Dengan adanya motivasi yang tinggi dari karyawan, diharapkan mereka akan lebih mencintai pekerjaannya, mampu bekerja lebih baik, memiliki loyalitas yang tinggi serta berkeinginan untuk melakukan kinerja yang lebih baik.
PT. Perkebuan Nusantara IV (Persero) adalah Badan Usaha Milik Negara (BUMN) yang bergerak di bidang perkebunan dan pengolahan buah kelapa sawit menjadi minyak kelapa sawit mentah. Walaupun sudah menjadi perusahaan besar tentu saja masih banyak hambatan yang dialami perusahaan baik itu berasal dari internal dan eksternal, diantaranya kinerja karyawan yang masih belum maksimal, hal ini dikarenakan faktor kepemimpinan yang masih cenderung belum mampu menggerakkan seluruh potensi sumberdaya manusia, belum mampu mengarahkan karyawannya terhadap tugas dan fungsinya dengan baik dan kurangnya sanksi yang tegas terhadap karyawan yang melanggar aturan. Disamping itu, faktor motivasi kerja juga menjadi tolak ukur dalam pengukuran kinerja, hal ini karena karyawan belum menunjukkan motivasi kerja yang tinggi dalam mencapai tujuan organisasi.

\section{METODE PENELITIAN \\ Lokasi Penelitian}

Penelitian ini dilakukan pada PT. Perkebunan Nusantara IV (Persero) yang berlokasi di Jl.Letjend Soeprapto No.2 Medan. No telp : 061-4154666

\section{Populasi Dan Sampel}

Populasi dalam penelitian ini adalah seluruh karyawan bagian pemasaran dan bagian sumberdaya manusia yang berjumlah 63 orang. Dimana 42 orang dari bagian SDM dan 21 orang dari bagian pemasaran. Dalam penelitian ini, teknik pengambilan sampel yang digunakan adalah metode total sampling, dimana peneliti mengambil seluruh jumlah populasi yaitu sebanyak 63 orang. 


\section{Analisis Data}

Teknik analisis data yang digunakan dalam penelitian ini untuk mengetahui seberapa besar variable Kepemimpinan dan variable motivasi kerja berpengaruh terhadap variable kinerja karyawan adalah Analisis Jalur (Path Analysis). "Analisis jalur digunakan untuk menganalisis pola hubungan antar variable dengan tujuan untuk mengetahui pengaruh langsung maupun tidak langsung seperangkat variable eksogen terhadap variabel endogen" (Riduwan dan Kuncoro, 2007:2).

\section{Pengujian Hipotesis \\ Uji t Parsial}

Untuk pengujian hipotesis menggunakan uji $\mathrm{t}$ (parsial) yaitu pengujian regresi secara terpisah atau parsial antar masing-masing variabel independen terhadap variabel dependen. Pengujian ini digunakan untuk mengetahui apakah masingmasing variabel bebasnya secara sendiri-sendiri berpengaruh secara signifikan terhadap variabel terikatnya.

Dimana $\mathrm{T}_{\text {Hitung }}>\mathrm{T}_{\text {Tabel }}$, H1 diterima.

$>$ Dan jika $\mathrm{T}_{\text {Hitung }}<\mathrm{T}_{\text {Tabel }}$, maka $\mathrm{H} 0$ ditolak.

\section{Uji F Simultan}

Selanjutnya menggunakan uji F (Simultan) yaitu pengujian regresi secara simultan atau serentak antara variabel independen terhadap variabel dependen. Uji F dimaksudkan untuk menguji ada tidaknya pengaruh variabel independen secara bersamasama terhadap variabel dependen atau untuk menguji tingkat keberartian hubungan seluruh koefisien regresi variabel independen terhadap variabel dependen.

Untuk menguji keberartian koefisien jalur secara keseluruhan digunakan uji $\mathrm{F}$ dengan rumus sebagai berikut:

$$
\mathrm{F}=\frac{(\mathrm{n}-\mathrm{k}-1) \mathrm{R}^{2} \mathrm{y}\left(\mathrm{X}_{1} \underline{\mathrm{X}}_{2}\right)}{\mathrm{k}\left(1-\mathrm{R} 2 \mathrm{Y}\left(\mathrm{X}_{1} \mathrm{X}_{2}\right)\right.}
$$

Dimana Fhitung $>$ Ftabel, maka H1 diterima atau secara bersama-sama variabel bebas dapat menerangkan variabel terikatnya secara serentak. Sebaliknya apabila Fhitung $<$ Ftabel, maka H0 diterima atau secara bersama-sama variabel bebas tidak memiliki pengaruh terhadap variabel terikat. Untuk mengetahui signifikan atau tidak pengaruh secara bersama-sama variabel bebas terhadap variabel terikat maka digunakan probability sebesar 5\% $(\alpha=0,05)$.

\section{Koefisien Determinan $\left(\mathbf{R}^{\mathbf{2}}\right)$}

Dari perhitungan $r$ ( korelasi ) dapat dilihat hubungan variabel bebas dan variabel terikat positif atau negative. Determinan digunakan untuk melihat kontribusi variabel bebas terhadap variabel terikat, dengan menggunakan rumus sebagai berikut :

$R^{2}=\begin{gathered}b\left(n \Sigma X_{1,2}\right)(\Sigma Y) \\ n\left(\Sigma Y^{2}\right)-(\Sigma Y)^{2}\end{gathered}$

Pengujian - pengujian di atas dilakukan dengan bantuan program pengolahan data Statistic Packages for Social Science (SPSS) versi 17.

HASIL PENELITIAN DAN
PEMBAHASAN
Hasil Penelitian
Analisis Jalur
$\quad$ Analisis jalur merupakan
bagian analisis regresi yang 
digunakan untuk menganalisis hubungan kausal antar variabel dimana variabel-variabel bebas mempengaruhi variabel tergantung, baik secara langsung maupun secara tidak langsung, melalui satu atau lebih variabel perantara.

\section{Kerangka hubungan antara jalur} ( $\mathrm{X}_{1}, \mathrm{X}_{2}$ terhadap $\left.\mathrm{Y}\right)$

Kerangka hubungan antara jalur $\left(\mathrm{X}_{1}\right.$, $\mathrm{X}_{2}$ terhadap $\mathrm{Y}$ ) dapat dibuat melalui persamaan variabel sebagai berikut :

$\mathrm{Y}=\rho_{y} X_{1}+\rho_{y} X_{2}+\rho_{y} \varepsilon 1$

Untuk mengetahui koefisien jalur dapat dilihat dari nilai Beta pada tabel Coefficients berikut

Tabel 1. Analisis Regresi Coefficients

\begin{tabular}{|c|c|c|c|c|c|}
\hline \multirow[b]{2}{*}{ Model } & \multicolumn{2}{|c|}{$\begin{array}{l}\text { Unstandardi } \\
\text { zed } \\
\text { Coefficients }\end{array}$} & \multirow{2}{*}{$\begin{array}{c}\begin{array}{c}\text { Standardi } \\
\text { zed } \\
\text { Coefficien } \\
\text { ts }\end{array} \\
\\
\text { Beta }\end{array}$} & \multirow[b]{2}{*}{$t$} & \multirow[b]{2}{*}{ Sig } \\
\hline & B & $\begin{array}{l}\text { Std. } \\
\text { Error }\end{array}$ & & & \\
\hline 1 (Constant) & 3.552 & 3.317 & & $\begin{array}{r}1.0 \\
71\end{array}$ & $\begin{array}{r}.28 \\
9\end{array}$ \\
\hline $\begin{array}{l}\text { Kepemimpi } \\
\text { nan }\end{array}$ & .509 & .099 & .483 & $\begin{array}{r}5.1 \\
40\end{array}$ & $\begin{array}{r}.00 \\
0\end{array}$ \\
\hline $\begin{array}{l}\text { Motivasi } \\
\text { Kerja }\end{array}$ & .478 & .109 & .413 & $\begin{array}{r}4.3 \\
95\end{array}$ & $\begin{array}{r}.00 \\
0\end{array}$ \\
\hline
\end{tabular}

a. Dependent Variable:

Kinerja Karyawan

Sumber : Data diolah, 2016

Dari tabel tersebut diketahui masing-masing koefisien jalur dari tiap variabel, dan didapatkan persamaan sebagai berikut :

$\mathrm{Y}=0,483 \mathrm{X}_{1}+0,413 \mathrm{X}_{2}+0,630 \varepsilon 1$

\section{Uji Koefisien Determinasi}

Untuk mengetahui nilai $\mathrm{R}^{2}$ dapat dilihat Model Summary berikut ini :
Tabel 2. Hasil Uji Koefisien Determinasi

Model Summary

\begin{tabular}{l|c|r|r|r|}
\hline Model & $\mathrm{R}$ & $\begin{array}{c}\mathrm{R} \\
\text { Square }\end{array}$ & $\begin{array}{c}\text { Adjusted R } \\
\text { Square }\end{array}$ & $\begin{array}{c}\text { Std. Error } \\
\text { of the } \\
\text { Estimate }\end{array}$ \\
\hline 1 & $.776^{\mathrm{a}}$ & .603 & .590 & 2.95215 \\
\hline $\begin{array}{l}\text { a. Predictors: } \\
\text { Kepemimpinan }\end{array}$ & (Constant), Motivasi Kerja,
\end{tabular}

b. Dependent Variable: Kinerja Karyawan

Besarnya angka $\mathrm{R}^{2}$ adalah 0,603. Angka tersebut dapat digunakan untuk melihat besarnya pengaruh Kepemimpinan dan motivasi kerja terhadap kinerja karyawan dengan menghitung koefisien determinasi sebesar 0,603. Angka tersebut maksudnya adalah bahwa Kepemimpinan dan motivasi kerja secara bersama-sama berpengaruh terhadap kinerja karyawan adalah $60,3 \%$, dan $60,3 \%$ disebabkan oleh variabel-variabel lain di luar model ini.

Menguji koefisien jalur secara keseluruhan (Simultan) Uji hipotesis secara keseluruhan model jalur tersebut sudah benar atau layak, dapat digunakan nilai $\mathrm{F}$ dari tabel 3 . ANOVA

\section{Tabel 3. Hasil Uji F Simultan} ANOVA $^{\mathrm{D}}$

\begin{tabular}{l|c|r|r|r|r|}
\hline Model & $\begin{array}{c}\text { Sum of } \\
\text { Squares }\end{array}$ & df & $\begin{array}{c}\text { Mean } \\
\text { Square }\end{array}$ & F & Sig. \\
\hline $\begin{array}{l}\text { 1 Regressio } \\
\mathrm{n}\end{array}$ & 793.933 & 2 & 396.96 & 45.54 & .000 \\
Residual & 522.912 & 6 & 8.715 & & \\
& 0 & & \\
Total & 1316.84 & 6 & & & \\
& 5 & 2 & & & \\
\hline
\end{tabular}
Kerja, Predictors: (Constant), Motivasi
b. Depenimpinan
Kinerja Karyawan Variable:


Sumber : Data diolah, 2016

Pada tabel Anova didapat nilai $F$ sebesar 45,549, dan nilai $F$ tabel dengan taraf signifikan $5 \%$ dan derajat kebebasan (dk) $(2,60)=$ 3,15.Sehingga diperoleh nilai $F$ hitung $>\mathrm{F}$ tabel ; 45,549> 3,15; maka Ho ditolak dan $\mathrm{Hi}$ diterima. Disimpulkan bahwa ada pengaruh signifikan antara kepemimpinan dan motivasi kerja terhadap kinerja karyawan PT. Perkebunan Nusantara IV (Persero) Medan.

\section{Menguji Koefisien Jalur Secara Individu (Parsial)}

Uji secara individual ditunjukan ada nilai $\mathrm{t}$ oleh tabel Coefficients.

Tabel 4. Hasil Uji t (Parsial) Coefficients $^{\mathrm{a}}$

\begin{tabular}{|c|c|c|c|c|c|}
\hline \multirow[b]{2}{*}{ Model } & \multicolumn{2}{|c|}{$\begin{array}{c}\text { Unstandardi } \\
\text { zed } \\
\text { Coefficients }\end{array}$} & \multirow{2}{*}{\begin{tabular}{|c|}
$\begin{array}{c}\text { Standardi } \\
\text { zed } \\
\text { Coefficien } \\
\text { ts }\end{array}$ \\
Beta \\
\end{tabular}} & \multirow[b]{2}{*}{$\mathrm{t}$} & \multirow[b]{2}{*}{ Sig } \\
\hline & B & $\begin{array}{l}\text { Std. } \\
\text { Error }\end{array}$ & & & \\
\hline 1 (Constant) & $\begin{array}{r}3.55 \\
2\end{array}$ & 3.317 & & $\begin{array}{r}1.0 \\
71\end{array}$ & $\begin{array}{r}.28 \\
9\end{array}$ \\
\hline $\begin{array}{l}\text { Kepemimpi } \\
\text { nan }\end{array}$ & .509 & .099 & .483 & $\begin{array}{r}5.1 \\
40\end{array}$ & $\begin{array}{r}.00 \\
0\end{array}$ \\
\hline $\begin{array}{l}\text { Motivasi } \\
\text { Kerja }\end{array}$ & .478 & .109 & .413 & $\begin{array}{r}4.3 \\
95\end{array}$ & $\begin{array}{r}.00 \\
0\end{array}$ \\
\hline
\end{tabular}

a. Pengaruh antara Kepemimpinan dengan kinerja karyawan

Dari hasil perhitungan SPSS diperoleh nilai t-hitung untuk kepemimpinan sebesar 5,140 ; dan besarnya t-tabel dengan ketentuan dengan taraf signifikan $5 \%$ dan derajat kebebasan (dk) dengan ketentuan $\mathrm{dk}=\mathrm{n}-2-1$, atau $63-2-1=$ 60 dan dari ketentuan itu diperoleh nilai $\mathrm{t}$ tabel 2,00. Didasarkan hasil perhitungan, diperoleh nilai thitung5,140> t-tabel sebesar 2,00; maka Ho ditolak dan Hi diterima. Artinya, ada pengaruh positif dan signifikan antara Kepemimpinandengan kinerja karyawan. Semakin baik kepemimpinan, maka kinerja karyawan pada PT. Perkebunan Nusantara IV (Persero) akan semakin meningkat.

b. Pengaruh antara Motivasi kerja dan kinerja karyawan

Dari hasil perhitungan SPSS diperoleh nilai t-hitung untuk variabel motivasi kerja sebesar 4,395 ; dan besarnya t-tabel dengan ketentuan dengan taraf signifikan $5 \%$ dan derajat kebebasan (dk) dengan ketentuan $\mathrm{dk}=\mathrm{n}-2-1$, atau 63-2-1 = 60 dan dari ketentuan itu diperoleh nilai t-tabel 2,00.Didasarkan hasil perhitungan, diperoleh nilai t-hitung sebesar 4,395> t-tabel sebesar 2,00; maka Ho ditolak dan Hi diterima. Artinya, ada pengaruh positif dan signifikan antara motivasi kerja dan kinerja karyawan. Semakin tinggi motivasi kerja karyawan, maka kinerja karyawan pada PT. Perkebunan Nusantara IV (Persero) akan semakin meningkat.

\section{Menghitung Pengaruh Secara Proporsional}

Model analisis jalur (Path analysis) digunakan untuk menganalisis pola hubungan antar variabel dengan tujuan untuk mengetahui pengaruh langsung dan pengaruh tidak langsung seperangkat variabel bebas (eksogen) terhadap variabel terikat (endogen).

Untuk mengetahui nilai korelasi antar variabel dapat dilihat dari tabel berikut : 
Tabel 5. Uji Korelasi Correlations

\begin{tabular}{|c|c|c|c|c|}
\hline & & $\begin{array}{c}\text { Kepemimp } \\
\text { inan }\end{array}$ & $\begin{array}{c}\text { Motiv } \\
\text { asi } \\
\text { Kerja }\end{array}$ & $\begin{array}{c}\text { Kinerja } \\
\text { Karya } \\
\text { wan }\end{array}$ \\
\hline \multirow[t]{3}{*}{$\begin{array}{l}\text { Kepemimp } \\
\text { inan }\end{array}$} & $\begin{array}{l}\text { Pearso } \\
\mathrm{n} \\
\text { Correla } \\
\text { tion }\end{array}$ & 1 & $.500^{* *}$ & $689^{*+}$ \\
\hline & $\begin{array}{l}\text { Sig. (2- } \\
\text { tailed) }\end{array}$ & & .000 & . 000 \\
\hline & $\mathrm{N}$ & 63 & 63 & 63 \\
\hline \multirow[t]{3}{*}{$\begin{array}{l}\text { Motivasi } \\
\text { Kerja }\end{array}$} & $\begin{array}{l}\text { Pearso } \\
\mathrm{n} \\
\text { Correla } \\
\text { tion }\end{array}$ & .500 & 1 & $.654^{*}$ \\
\hline & $\begin{array}{l}\text { Sig. (2- } \\
\text { tailed) }\end{array}$ & .000 & & .000 \\
\hline & $\mathrm{N}$ & 63 & 63 & 6 \\
\hline \multirow[t]{3}{*}{\begin{tabular}{|l|} 
Kinerja \\
Karyawan
\end{tabular}} & $\begin{array}{l}\text { Pearso } \\
\mathrm{n} \\
\text { Correla } \\
\text { tion }\end{array}$ & .689* & $.654^{* *}$ & \\
\hline & $\begin{array}{l}\text { Sig. (2- } \\
\text { tailed) }\end{array}$ & .000 & .000 & \\
\hline & $\mathrm{N}$ & 63 & 63 & 6 \\
\hline
\end{tabular}

${ }^{* *}$. Correlation is significant at the 0.01 level (2-tailed).

Untuk menafsir angka tersebut digunakan kriteria sebagai berikut:

$0-0,25$ korelasi sangat lemah (dianggap tidak ada) $>0,25-0,5 \quad$ : $\quad$ korelasi cukup

$>0,5-0,75$

: korelasi kuat

$>0,75-1$ korelasi

sangat kuat

Dari tabel 5. Uji Korelasi di atas dapat disimpulkan bahwa :

\section{a. Korelasi}

\section{Kepemimpinandengan Motivasi Kerja Karyawan}

Berdasarkan perhitungan diperoleh angka korelasi antara variabel Kepemimpinandan motivasi kerja sebesar 0,500. Korelasi sebesar 0,500 mempunyai maksud hubungan antara variabel

Kepemimpinandengan motivasi kerja karyawan adalah cukup. Korelasi kedua variabel tersebut bersifat signifikan karena signifikansinya sebesar 0.476 dimana apabila angka signifikansi ( $\mathrm{sig}$ ) $0,000<0,05$ maka hubungan kedua variabel signifikan.

\section{b. Korelasi}

antara

Kepemimpinandan

kinerja karyawan

Berdasarkan perhitungan diperoleh angka korelasi antara variabel Kepemimpinandengan kinerja karyawan sebesar 0,689. Korelasi tersebut menunjukkan hubungan antara Kepemimpinandengan kinerja karyawan adalah kuat dan searah. Korelasi kedua variabel juga bersifat signifikan (sig) sebesar 0,00<0,05.

\section{c. Korelasi antara Motivasi kerja dan Kinerja karyawan}

Berdasarkan perhitungan diperoleh angka korelasi antara variabel motivasi kerja dan kinerja karyawan sebesar 0,654. Korelasi tersebut menunjukkan hubungan antara motivasi kerja dan kinerja karyawan adalah kuat dan searah. Korelasi kedua variabel juga bersifat signifikan (sig) sebesar $0,000<0,05$.

\section{Diagram Jalur}

Persamaan struktural untuk diagram jalur di atas sebagai berikut :

$\mathrm{Y}=0,483 \mathrm{X}_{1}+0,413 \mathrm{X}_{2}+0,630 \varepsilon 1$

\section{Skema Diagram Jalur}

Besarnya pengaruh proporsional dapat sebagai berikut :

a. Pengaruh Kepemimpinan $\left(\mathrm{X}_{1}\right)$ terhadap Motivasi kerja $\left(\mathrm{X}_{2}\right)$

Pengaruh Langsung

$\mathrm{rX}_{1} \mathrm{X}_{2}{ }^{2}$

$$
\begin{aligned}
& = \\
& =0.500^{2} \\
& =0,250
\end{aligned}
$$


b. Pengaruh Kepemimpinan $\left(\mathrm{X}_{1}\right)$ terhadap kinerja karyawan $(\mathrm{Y})$

Pengaruh Langsung

$$
=\rho_{\mathrm{y}} \mathrm{X}_{1}{ }^{2}
$$

$0,483^{2}=0,233$

Pengaruh Tidak Langsung

$\mathrm{X}_{1}$ melalui $\mathrm{X}_{2}$

$$
=\rho_{\mathrm{y}} \mathrm{X}_{1} \text {. }
$$

$\mathrm{rX}_{1} \mathrm{X}_{2} \cdot \rho_{\mathrm{y}} \mathrm{X}_{2}$

$0,500.0,413$

$$
=0,483
$$

$$
=0,100
$$

c. Pengaruh motivasi kerja $\left(\mathrm{X}_{2}\right)$ terhadap kinerja karyawan $(\mathrm{Y})$

Pengaruh Langsung

$$
=\rho_{\mathrm{y}} \mathrm{X}_{2}{ }^{2}
$$

$0,413^{2}$

$$
=0,170
$$

Pengaruh Tidak Langsung

$\mathrm{X}_{1}$ melalui $\mathrm{X}_{2}$

$=\rho_{\mathrm{y}} \mathrm{X}_{2}$.

$\mathrm{rX}_{1} \mathrm{X}_{2} \cdot \rho_{\mathrm{y}} \mathrm{X}_{1}$

$0,500.0,483$

$=0,413$

d. Pengaruh

$=0,100$

Kepemimpinan $\left(\mathrm{X}_{1}\right)$, Motivasi Kerja $\left(\mathrm{X}_{2}\right)$ terhadap kinerja karyawan $(\mathrm{Y})$

$$
\mathrm{r}^{2} \mathrm{Y}\left(\mathrm{X}_{1} \cdot \mathrm{X}_{2}\right)=
$$

$\left|\begin{array}{ll}\rho y X_{1} & \rho y X_{2}\end{array}\right|\left|\begin{array}{l}r_{y} X_{1} \\ r_{y} X_{2}\end{array}\right|$

$\mathrm{r}^{2} \mathrm{Y}\left(\mathrm{X}_{1} . \mathrm{X}_{2}\right)=$

$\left|\begin{array}{ll}0,483 . & 0,413 \mid\end{array}\right| \begin{aligned} & 0,689 \\ & 0,654\end{aligned} \mid$

$$
\begin{aligned}
& =0.333+0,270 \\
& =0,603 \quad \text { (angka }
\end{aligned}
$$

tersebut adalah koefisien determinasi)

Hasil penelitian ini dapat diringkas

\begin{tabular}{|c|c|c|c|c|c|}
\hline \multirow{2}{*}{\multicolumn{2}{|c|}{ Variabel }} & \multirow{3}{*}{$\begin{array}{c}\begin{array}{c}\text { Koefi } \\
\text { sien } \\
\text { Jalur }\end{array} \\
0,483\end{array}$} & \multicolumn{3}{|c|}{$\begin{array}{c}\text { Pengaruh Terhadap } \\
Y\end{array}$} \\
\hline & & & \multirow{2}{*}{$\begin{array}{c}\begin{array}{c}\text { Langs } \\
\text { ung }\end{array} \\
0,233\end{array}$} & \multirow{2}{*}{$\begin{array}{c}\begin{array}{c}\text { Tidak } \\
\text { Langs } \\
\text { ung }\end{array} \\
0,100\end{array}$} & \multirow{2}{*}{$\begin{array}{c}\begin{array}{c}\text { Tot } \\
\text { al }\end{array} \\
0,3 \\
33\end{array}$} \\
\hline $\begin{array}{l}\text { Peng } \\
\text { aruh }\end{array}$ & $\begin{array}{c}X \\
1 \\
\end{array}$ & & & & \\
\hline $\begin{array}{l}\text { Parsi } \\
\text { al }\end{array}$ & $\begin{array}{l}X \\
2\end{array}$ & 0,413 & 0,170 & 0,100 & $\begin{array}{c}0,2 \\
70\end{array}$ \\
\hline \multicolumn{5}{|c|}{ Pengaruh simultan $\mathrm{X}_{1}$ dan $\mathrm{X}_{2}$} & $\begin{array}{c}0,6 \\
03 \\
\end{array}$ \\
\hline \multicolumn{5}{|c|}{ Pengaruh Variabel lalin } & $\begin{array}{l}0,3 \\
97 \\
\end{array}$ \\
\hline \multicolumn{5}{|c|}{ Pengaruh Variabel $\mathrm{X}_{1}$ terhadap $\mathrm{X}_{2}$} & $\begin{array}{l}0,2 \\
50 \\
\end{array}$ \\
\hline
\end{tabular}
seperti tabel berikut :

Tabel 6. Koefisien Jalur, Pengaruh Langsung, Tidak Langsung, Pengaruh Total, dan Pengaruh Kepemimpinan $\left(\mathrm{X}_{1}\right)$; Motivasi
Kerja $\left(X_{2}\right)$; secara simultan dan signifikan terhadap Kinerja karyawan (Y)

1. Pengaruh langsung Kepemimpinan $\left(\mathrm{X}_{1}\right)$ terhadap kinerja karyawan (Y) sebesar 0,233 atau $23,3 \%$

2. Pengaruh langsung Kepemimpinan $\left(\mathrm{X}_{1}\right)$ terhadap Motivasi kerja $\left(\mathrm{X}_{2}\right)$ sebesar 0,250 atau $25 \%$.

3. Pengaruh langsung motivasi kerja $\left(\mathrm{X}_{2}\right)$ terhadap kinerja karyawan (Y) sebesar 0,170 atau $17,0 \%$.

4. Pengaruh Kepemimpinan $\left(\mathrm{X}_{1}\right)$ dan motivasi kerja $\left(\mathrm{X}_{2}\right)$ secara simultan terhadap kinerja karyawan (Y) sebesar 0,603 atau $60,3 \%$. Sisanya yaitu 0,397 atau sebesar $39,7 \%$ dipengaruhi oleh faktor-faktor lain yang tidak dapat dijelaskan dalam penelitian ini.

\section{Pembahasan Hasil Penelitian}

Berdasarkan hasil penelitian dan tanggapan dari responden mengenai Kepemimpinan pada PTPN IV (Persero) Medan dinyatakan sudah cukup baik, adanya rasa tanggung jawab terhadap pekerjaan yang telah diberikan kepada mereka. Pemimpin mempunyai peran yang sangat erat menentukan dalam pelaksanaan organisasi perusahaan, karena 
pemimpin merupakan titik sentral didalam menentukan sumber-sumber yang ada untuk terciptanya suatu tujuan perusahaan.

Berdasarkan hasil penelitian yang dilakukan terhadap 63orang karyawan pada PT Perkebunan Nusantara IV (Persero) Medan diperoleh hasil bahwa kepemimpinan mempunyai pengaruh langsung terhadap kinerja karyawan yaitu sebesar 0,233(23,3\%) begitu juga untuk motivasi kerja memiliki pengaruh secara langsung terhadap kinerja karyawan sebesar 0,170 (17\%). Hasil analisis korelasi menunjukkan kepemimpinan mempunyai pengaruh langsung terhadap motivasi kerja karyawan sebesar 0,250 (25\%).

Berdasarkan analisis $R$ square sebesar 0,603 artinya bahwa variabel kepemimpinan dan motivasi kerja berpengaruh sebesar $60,3 \%$ dan sisanya sebesar 39,7 \% dijelaskan oleh faktor lain diluar analisa variabel dalam penelitian ini seperti disiplin kerja, semangat kerja, dan lingkungan kerja. Berdasarkan hasil penelitian terbukti bahwa Kepemimpinan dan Motivasi Kerja bersama-sama mempunyai pengaruh yang positif terhadap Kinerja Karyawan PT Perkebunan Nusantara IV (Persero) Medan.

Perhitungan pengaruh kepemimpinan dan motivasi kerja terhadap kinerja karyawan secara parsial dapat dilihat berdasarkan tabel Coefficient. Berdasarkan hasil perhitungan yang dilakukan untuk melihat pengaruh Kepemimpinan dengan kinerja diperoleh angka $\mathrm{t}$ hitung $(5,140)>\mathrm{t}$ tabel $(2,00)$. Maka dapat disimpulkan Ho ditolak dan $\mathrm{H}_{1}$ diterima. Artinya ada pengaruh antara kepemimpinan dengan kinerja karyawan. Besarnya pengaruh kepemimpinan dan kinerja karyawan sebesar 0,233 atau 23,3\%.Artinya Kepemimpinan memang sangat diperlukan oleh seorang karyawan untuk dapat mencapai suatu kinerja yang tinggi.

Berdasarkan hasil perhitungan yang dilakukan untuk melihat pengaruh antara motivasi kerja dengan kinerja karyawan diperoleh angka $\mathrm{t}$ hitung $(4,395)>\mathrm{t}$ tabel $(2,00)$. Maka dapat disimpulkan $\mathrm{Ho}$ ditolak dan $\mathrm{H}_{1}$ diterima. Artinya ada pengaruh antara motivasi kerja dengan kinerja karyawan. Besarnya pengaruh motivasi kerja terhadap kinerja karyawan sebesar 0,170 atau $17 \%$ dianggap positif dan signifikan artinya motivasi kerja dalam perusahaan merupakan hal yang penting bagi karyawan. Karena dengan memiliki motivasi kerja dapat meningkatkan gairah dan semengat kerja karyawan sehingga karyawan dapat bekerja semaksimal mungkin untuk mencapai tujuan perusahaan. Dalam hal ini, pemimpin perlu mengetahui seberapa besar keinginan karyawan untuk bekerja dengan giat guna memenuhi kebutuhannya sehingga perusahaan dapat mengambil keputusan yang bijaksana yang nantinya diharapkan karyawan dapat bekerja sesuai standar yang diinginkan perusahaan.

Perhitungan pengaruh antara Kepemimpinan dan motivasi kerja secara gabungan terhadap kinerja karyawan (dilihat berdasarkan tabel anova) diperoleh angka signifikansi sebesar $0,000<0,05$ yang berarti ada hubungan yang linear antara kepemimpinan dan motivasi kerja terhadap kinerja karyawan $\left(\mathrm{H}_{1}\right.$ diterima). Demikian halnya jika dibandingkan dengan $\mathrm{F}$ tabel $(2,60)=$ 
3,15maka diperoleh $\mathrm{F}$ hitung $(45,549)$ $>\mathrm{F}$ tabel $(3,15)$ yang berarti H1 diterima.Kinerja Karyawan yang baik di PT Perkebunan Nusantara IV (Persero) Medan karena adanya dorongan dari Kepemimpinan dan motivasi kerja yang kuat di PT Perkebunan Nusantara IV (Persero) Medan tersebut.

Dari berbagai uraian diatas maka dapat disimpulkan bahwa Kepemimpinan dan motivasi kerja mempengaruhi kinerja karyawan, dan hal tersebut menjadi pertimbangan agar faktor-faktor tersebut mampu untuk lebih meningkatkan kinerja karyawan PT Perkebunan Nusantara IV (Persero) Medan.

\section{PENUTUP}

Berdasarkan hasil dan pembahasan penelitian sebagaimana telah diuraikan diatas, maka dapat dibuat beberapa kesimpulan, yaitu :

1. Pengaruh langsung Kepemimpinan $\left(\mathrm{X}_{1}\right)$ terhadap kinerja karyawan (Y) sebesar 0,233 atau $23,3 \%$.

2. Pengaruh langsung Kepemimpinan $\left(\mathrm{X}_{1}\right)$ terhadap Motivasi kerja $\left(\mathrm{X}_{2}\right)$ sebesar 0,250 atau $25 \%$.

3. Pengaruh langsung motivasi kerja $\left(\mathrm{X}_{2}\right)$ terhadap kinerja karyawan $(\mathrm{Y})$ sebesar 0,170 atau $17,0 \%$.

4. Pengaruh Kepemimpinan $\left(\mathrm{X}_{1}\right)$ dan motivasi kerja $\left(\mathrm{X}_{2}\right)$ secara simultan terhadap kinerja karyawan (Y) sebesar 0,603 atau $60,3 \%$. Sisanya yaitu 0,397 atau sebesar $39,7 \%$ dipengaruhi oleh faktor-faktor lain yang tidak dapat dijelaskan dalam penelitian ini.

\section{DAFTAR PUSTAKA}

Aditya, Regina. 2010. Pengaruh Gaya Kepemimpinan, Motivasi dan Disiplin Kera terhadap Kinerja Karyawan PT.Sinar Sentosa Perkasa Banjarnegara. Jurnal. Universitas Diponegoro. ISSN 1412-86676 Vol.11 No.24

Agustini, Fauziah. 2011. Manajemen Sumber Daya Manusia Lanjutan. Medan : Madenatera

Arikunto, Suharsimin. 2010. Manajemen penelitian. Jakarta: Rineka Cipta

Amirullah dan Budiyono. 2004. Pengantar Manajemen. Edisi Kedua. Yogyakarta: Graha Ilmu

Fadhillah, Adianti. 2013. Pengaruh Motivasi Kerja dan Budaya Organisasi Terhadap Kepuasan Kerja Karyawan PT.Perkebunan Nusantara IV (Persero) Unit Kebun Balimbingan. Universitas Negeri Medan

Hakim, Abdul. 2006. Analisis Pengaruh Motivasi, Komitmen Organisasi dan Iklim Organisasi terhadap Kinerja Pegawai pada Dinas Perhubungan dan Telekomunikasi Provinsi Jawa Tengah. Jrbi. Vol.2. No. 2

Hasibuan, Malayu SP. 2003. Manajemen Sumber Daya Manusia. Edisi Revisi. Jakarta: Bumi Aksara.

Irawati. 2011. Pengaruh Motivasi dan Budaya Organisasi terhadap Kinerja 
Karyawan

pada

PT.Perkebunan Nusantara II (Persero) Distrik Rayon

Selatan Medan. Skripsi. Universitas Negeri Medan

Kuncoro, Mudrajat. 2009. Metode

Riset untuk Bisnis dan Ekonomi Edisi 3. Jakarta: Erlangga

Kurniawan, Agung. 2012. Pengaruh

Kepemimpinan dan

Pengembangan Sumber Daya Manusia terhadap Kepuasan Kerja, Motivasi Kerja dan Kinerja Karyawan Bank Sulselbar. Jurnal. Universitas Negeri Makassar. ISSN 1411-0393 Vol.16 No.4

Linawati dan Suhaji. 2011. Pengaruh Motivasi, Kompetensi, Kepemimpinan dan Lingkungan Kerja terhadap Kinerja Karyawan PT.Herculon Carpet Semarang. Jurnal. Sekolah Tinggi Ilmu Ekonomi Widya Manggala

Mangkunegara, AA, Anwar Prabu. 2010. Manajemen Sumber Daya Manusia. Bandung. Remaja Roskarya

Martoyo, susilo. 2011. Manajemen Sumber Daya Manusia. Rineka cipta, Jakarta.

Marwansyah. 2010 http://www.google.com/me nurut + marwansyah + organisasi (17 maret 2014)

Muhidin S.A. 2007. Analisis Korelasi, Regresi, Jalur Dalam Penelitian. Bandung: Pustaka Setia.

Prabu, Anwar. 2005. Pengaruh Motivasi terhadap Kepuasan Kerja Pegawai

$\begin{array}{lrr}\text { Badan } & \text { Koordinasi } \\ \text { Keluarga } & \text { Berencana } \\ \text { Nasional } & \text { Kabupaten } \\ \text { Muara Enim. } & \text { Jurnal } \\ \text { Manajemen dan } & \text { Bisnis } \\ \text { Sriwijaya. III.6.1-24 } & \end{array}$

Riduwan. 2007. Statiska untuk Penelitian. Bandung : Alfabeta

Riduwan, dkk. 2008. Cara Menggunakan dan Memakai Analisis Jalur (Path Analisys). Bandung : Alfabeta.

Rivai, Veithzal dan Basri. 2005. Performance Appraisal: Sistem yang Tepat Untuk Menilai Kinerja Karyawan dan Meningkatkan Daya Saing Perusahaan. Jakarta: PT.RAJAGRAFINDO PERSADA.

Rivai, dkk. 2009. Manajejen Sumber Daya Manusia Untuk Perusahaan. Jakarta : Raja Grafindo Persada.

Robbins, Stephens. 2008. Prilaku organisasi (Organizational Behaviour). Jakarta : Salemba Empat.

Said dan Subhan Z. 2012. Pengaruh Kepemimpinan, Motivasi dan Budaya Organisasi Terhadap Kinerja Pegawai Administrasi IAIN ArRaniry Banda Aceh. Jurnal. Universitas Syiah Kuala. ISSN 2302-0199 Vol.2 No.1

Sari, Rahmila. 2012. Pengaruh Pengaruh Kepemimpinan, Motivasi dan Stres Kerja Terhadap Kinerja Karyawan pada Bank Syariah Mandiri Kantor 
Cabang Makassar. ISSN 2303-1001 Vol.1 No.1

Siagian, Sondang P. 2007. Manajemen Sumber Daya Manusia. Jakarta: Bumi Aksara

Sopiah. 2008. Perilaku Organisasi. Yogyakarta: Andi

Sugihartono. 2012. Pengaruh Kepemimpinan dan Kepuasan Kerja Terhadap Kinerja Karyawan dengan Mediasi Komitmen PT. Alam Kayu Sakti Semarang. ISSN 2087-1090 Vol.3 No. 1

Sugiyono. 2003. Metode Penelitian Pendidikan. Bandung: Alfabeta

Suharyadi. 2009. Statistika untuk Ekonomi dan Keuangan Modern. Jakarta : Salemba Empat.

Suharyadi, Purwanto. 2009. Statistika Jilid 2. Jakarta : Salemba Empat

Terry, George R. 2006. PrinsipPrinsip Manajemen (Edisi Bahasa Indonesia). Bandung : PT.Bumi Aksara

Umar, Husein. 2003. Metode Riset Prilaku Organisasi. Jakarta : Gramedia.

Wibowo, 2007. Meningkatkan Kinerja Karyawan. Bandung:Bina Aksara 